Trakya Üniversitesi

Eğitim Fakültesi Dergisi

Cilt 8, Say1 2

Ocak 2018 178-194

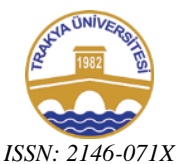

ISSN: $2146-071 X$
Trakya University

Journal of Education Faculty

Volume 8 , Issue 2

January 2018, 178-194

\title{
Öğretmen Adaylarının Yabancı Dil Derslerinde İngilizce Konuşma Kaygıları ile İlgili Algıları ${ }^{1}$
}

\section{Teacher Trainees' Perceptions on English Language Speaking Anxiety in Foreign Language Classes}

\section{Sabriye SSENER ${ }^{2}$}

Öz: Bu makale öğretmen adaylarının yabancı dil konuşma kaygısı konusundaki algılarını araştırmayı amaçlamaktadır. Araștırmanın katılımcıları Muğla Sttkı Koçman Üniversitesi'nin İngilizce Dil Eğitimi Bölümünün (ELT) 72 öğrencisi ve 3 öğretmen eğitmeninden oluşmaktadır. Çalışmada karma (mixed) araştırma deseni kullanılmıștır. Bu amaçla ilk olarak katılımcılara Yabancı Dil Snııf Kaygısı Ölçeği (FLCAS) uygulandı. Daha sonra nitel veriler, ölçeği tamamlayan altı öğrenciden yarı yapılandırılmış görüşmeler yoluyla toplanmıştır. En son olarak da, nitel veri toplamak için bölümden 3 öğretim üyesi ile görüşülmüştür. Nicel ve nitel verilerin analizleri, katıllmmcıların orta düzeyde yabancı dil kaygısı yaşadıklarını ortaya koymuştur. Öğretmen adaylarının kaygılarını, hata yapma korkusu, olumsuz değerlendirilme korkusu, hatalarını derhal düzeltme çabası, rekabetçi sınıf ortamı, resmi olmayan dil kullanımı gibi durumların etkilemiş olduğu belirlenmiştir.

Anahtar sözcükler: Yabancı dil sinıf kaygısl, konuşma endişesi, duygusal bireysel faktörler.

\begin{abstract}
This paper aims at exploring the perceptions of teacher trainees' foreign language speaking anxiety. The participants of the study include 72 English Language Teaching Department (ELT) trainees, and 3 instructors of Muğla Sttkı Koçman University. In the study a mixed design research methodology was employed. To this end, firstly the participants were administered the Foreign Language Classroom Anxiety Scale (FLCAS).Then the qualitative data were collected by means of semi-structured interviews from six students who completed the scale. Finally, three ELT department instructors were interviewed to gather qualitative data. The analyses of the data showed that participants had a moderate level of foreign language anxiety and anxiety provoking situations were found to be making mistakes, fear of negative evolution, immediate error correction, competitive classroom environment, formal language use, peer pressure that affects students' English language learning anxiety.
\end{abstract}

Keywords: Foreign language classroom anxiety, speaking anxiety, affective individual factors

\footnotetext{
${ }^{1}$ This paper was presented as an oral presentation at 5 th International Research Meetings in Education (ICRE 2015) held at Trakya University on October 8-10, 2015.

2 Yrd. Doç. Dr., Muğla Sitkı Koçman Üniversitesi, e-posta: sabriyesener@mu.edu.tr
} 


\section{INTRODUCTION}

Anxiety is described as an uncontrollable state that can make the language learning situation problematic and stressful. Brown (2000) indicates that anyone may experience anxiety associated with feelings of uneasiness, frustration, self-doubt, apprehension, or worry. For Gas and Selinker (2008), it is a situation that cannot be controlled and makes the language learning hard and full of stress. Horwitz et al., (1986) state that subjective feelings such as stress, apprehension, nervousness and worry can be the reasons of anxiety. They point out that the effects of foreign language anxiety are seen in the foreign language classroom and it is a powerful sign of achievement. They list three types of anxiety; communication apprehension; test anxiety; and fear of negative evaluation. In foreign language classes, learners may have a feeling of growing unease and become dissatisfied with what they do, or may have concerns about what they say while using the foreign language. These negative feelings might be seen while they are doing speaking, writing or reading and listening activities. Horwitz (2001) suggests that language learning anxiety should be separated from other kinds of anxiety and thinks it has significant negative effects on language performance.

Recently foreign language researchers have paid remarkable amount of attention to the impact of anxiety on language learning and indicated that it is most closely related to the acquisition of a foreign language. They also stated that anxiety creates difficulties for learners and makes it difficult to reach their goals. Additionally, learners' unrealistic beliefs about language learning have a negative role on foreign language performance. (Horwitz et al., 1986) developed the Foreign Language Classroom Anxiety Scale (FLCAS) to measure the anxiety sources of university students. Several studies were carried out to explore the anxiety levels of learners by using their foreign language anxiety scale. In some of these studies the anxiety levels of the learners and the role of anxiety on foreign language learning have been studied (Ellis, 2008; Gardner \& MacIntyre, 1993; Horwitz et al.., 1986; MacIntyre \& Gardner, 1989; Young, 1990). Some researchers explored the existence of remarkable level of anxiety in foreign language classes in the Turkish context (Kunt, 2001; Şener, 2010; Şener and Çokçalışkan, 2016; Subaş1, 2010; Şenald1, 2016). Subaşı (2010) pointed out that speaking anxiety is a commonly faced problem. Data from semi-structured interviews, which was given to more anxious students according to the result of questionnaire, revealed that the first-year students were not satisfied with their speaking performance.

Language anxiety generally has been found to have a negative effect on learning. Horwitz et al., (1986) found a negative correlation between foreign language anxiety and students' expected scores in a language class in the study. Their research indicated that students who had higher levels of foreign language anxiety both expected and received lower grades than those with less anxiety. Some other researchers also found a negative correlation between students' foreign language classroom anxiety and their achievement. Aida (1994) revealed a significant negative correlation between FLCAS scores and final grades of American second-year Japanese students. Kim, (1998) also found a negative relationship between anxiety levels and final grades. In some recent studies, in the Iranian context, Amiri and Ghonsooly (2015) showed that high anxiety had a negative effect on students' achievement. They also revealed that females were more anxious than males, and the "fear of negative evaluation" was the most provocative factor increasing the anxiety 
level of the learners. Rastegar and Karami (2013), too, determined a negative relationship between foreign language class anxiety and success of the participants.

In the Turkish context, a number of researchers found a negative relationship between anxiety and foreign language success (Batumlu and Erden, 2007; Şener, 2010, 2015; Şener and Çokçalışkan, 2016). However, in limited number of studies language anxiety showed a positive effect on learning. Chastain (1975) found that anxiety positively affected the scores. In other words, learners with higher levels of anxietywere better in the exams. Brown (2000) posits that anxiety can facilitate learning. Eysenck and MacIntyre (1979; 2002, as cited in Ellis, 2008) consider that learners with low level of anxiety can spend more effort, which leads to higher motivation. In an Asian context, Khairi and Nurul Lina (2010), too, found that moderate level of anxiety in foreign language learning might increase motivation in learning. In a recent study, Büyükkarc1, (2016) found that university students' anxiety does not correlate with their academic achievement and attitude.

Some others researchers focused on the principle causes of foreign language anxiety and examined the anxiety provoking situations (Aydın et al., 2006; Çelebi, 2009; Çubukçu; 2007; Öztürk and Gürbüz, 2014). Çelebi (2009) stated that speaking in front of others and speaking to native speakers may affect students' feelings of anxiety. She also reported six different anxiety factors in foreign language learning: personal and interpersonal anxieties; learners' beliefs about learning and instructors' beliefs about teaching; interactions between learners and teachers; classroom procedures and language testing. According to Çubukçu (2007), the main sources of anxiety were stated as: doing presentations in front of the class, making mistakes, afraid of losing respect, or being unable to express one-self, fear of being unsuccessful, and teachers' evaluation. Öztürk and Gürbüz (2014) showed in their study that students had a low level of speaking anxiety, and major causes of EFL speaking anxiety were the concern of correct pronunciation, questions asked by the teacher promptly, fear of making mistakes and negative evaluation. However, Aydin et al. in a study in 2006 found that participants usually had a high level of anxiety. They also found that younger learners felt less confident and more anxious than older students. In a later investigation, Aydin (2008) aimed to find out gender did not highly correlate with language anxiety and fear of negative evaluation. However, ages and grades were significantly related to fear of leaving unfavorable impressions on peers, disapproval by others, making mistakes in front of the class and teacher corrections during English classes. In a more recent study, Atas (2015) designed an action research to reduce, especially, the speaking anxiety of learners by using different techniques. The researcher examined how drama techniques affect speaking anxiety in foreign language classes. After six weeks' drama training and teaching drama techniques, she found that drama lowered students' anxiety levels and increased the self-confidence levels in foreign language classes. In a more recent study Bergström (2017) investigated the anxiety level and course level of Sweedish students and determined that low level students seemed to have higher level of anxiety. Among the reasons of their anxiety, they were found to be anxious about failing in the English classes. Additionally, students in English 7 seemed to be more anxious than the ones in English 5 level and girls expressed slightly higher communication apprehension than the males did.

While there is research available showing the relationship between anxiety and success, the present study aimed to define the anxiety level and students' and their instructors' perceptions related to anxiety provoking situations in foreign language 
classes. It also aims to explore the relationship between the junior and senior groups' anxiety levels in terms of their age and gender. This is the focus here. The following research questions were developed to achieve this aim:

1. What is the anxiety level of teacher trainees?

2. What are the anxiety level differences according to age, gender and class variables?

3. What are the sources of foreign language anxiety of the teacher trainees?

4. What are the suggestions of the instructors to reduce the anxiety level of the students?

\subsection{Research Design}

\section{METHODOLOGY}

In the present study a mixed research design was employed. The researcher collected both numeric information and qualitative data. She aimed to generate multiple perspectives on a single phenomenon by using multiple data sources. To name the sources of data, the researcher, firstly, aimed to obtain numeric data by means of a scale. Then, self-reflections, experience, opinions, and feelings of students were elicited through semi-structured interviews. Finally, qualitative data were collected from the trainers working at the ELT department by means of semistructured interviews.

\subsection{Setting and Participants}

The study was carried out at Muğla Sitkı Koçman University in the spring term of 2014-2015 academic year. The quantitative data were gathered from 72 university students, 26 juniors and 46 seniors. They were 53 females and 19 males. Their ages ranged between 18 and 25 . The qualitative data were gathered from two groups: The first group of participants included three teacher trainers working at the department, with different teaching experience of English, delivering theoretical and skill-based courses and in the second group there were 6 volunteer students, 3 from juniors and 3 from seniors.

\subsection{Instruments}

The quantitative data were gathered through the five-Likert Foreign Language Classroom Anxiety Scale (FLCAS) developed by Horwitz et al. (1986). This reliable scale (Cronbach's Alpha $=0.93$ ) has been used in various studies to measure anxiety levels of second or foreign language learners. The scale consisted of 33 statements, with 4 sub-categories measuring speaking, listening, test and general anxiety. The qualitative data were collected by means of semi-structured interviews with students and trainers. Five interview questions for the students and five questions for the instructors were adopted from Pappamihiel (2002).

\subsection{Data Collection and Analysis Procedures}

After getting authorization from the Department, the quantitative data were collected from the students during the class hours by the researcher on two different days. The participants were asked to write their names if they agreed to be a participant of interviews. It took them almost 20 minutes to complete the task. For the interviews, the researcher non-randomly determined the samples. 3 volunteers from the juniors and 3 from the seniors were included as participants. They were informed about the 
ethical issues and reminded that their personal information would not be used by anyone. The meetings were arranged one by one and face to face interviews were realized. To gather data from the trainers, face to face interviews were performed in their offices on their vacant days. The interviews were recorded and then transcribed word to word soon after the interviews.

The quantitative data gathered by means of the FLCAS scale were analyzed by using T-test, descriptive statistics in the Statistical Package for Social Sciences (SPSS, 22.0). In the qualitative analysis phase of the study, the grounded theory was applied. It was evolved by Glaser and Strauss (1967). The qualitative data analysis involved the process such as coding, categorizing, making sense of the essential meanings of the phenomenon. Firstly, the data were organized. Then the framework was identified. Explanatory framework was used because the analysis was guided by the research questions. The data were coded. Codes came from reading and thinking about the data. Coding represented key steps in the process. Charmaz (1983) described it as '...the process of categorizing and sorting data...' (p.111). After initial coding, the researcher turned back to change broke down codes. During and after coding, the connections between codes were searched. Responses were categorized and then the themes were identified. Themes were related to the research questions.

Reliability and validity issues are important in qualitative research. In order to provide reliability, it is a necessity to demonstrate that the methods used were reproducible and consistent. After coding and determining the categories, a colleague applied the same procedures. After checking the similarities and differences between the two researchers, the reliability was obtained with the inter-coder reliability using the formula suggested by Miles and Huberman (1994) and it was found reliable (0.85).

\subsection{Findings}

Firstly, the Cronbach's Alpha internal consistency coefficient was tested and was found to be highly reliable (0.94). The findings are presented below.

RQ 1. What is the anxiety level of teacher trainees?

Quantitative data analysis showed that students had a moderate level of foreign language anxiety. The mean of score of listening anxiety $(M=3.18)$ was the highest among other categories. This was followed by speaking anxiety $(M=2.86)$ and test anxiety $(M=2.84)$. Their general anxiety $(M=2.70)$ was found to be the lowest when compared to other sub-categories (See Table1).

Table1. Participants' anxiety level differences in four categories

\begin{tabular}{llll}
\hline Anxiety Category & N & Mean & Std. Deviation \\
\hline Speaking Anxiety & 72 & 2.86 & 1.06 \\
Listening Anxiety & 72 & 3.18 & .98 \\
Test Anxiety & 72 & 2.84 & .92 \\
General Anxiety & 72 & 2.70 & .82 \\
\hline
\end{tabular}

RQ2. What are the anxiety level differences according to gender, class, and age variables?

As can be seen in Table 2, according to the gender variable, there was not a significant difference between males and females' anxiety levels. 
Table2. Anxiety level differences between females and males

\begin{tabular}{lllcccc}
\hline $\begin{array}{c}\text { Anxiety } \\
\text { Category }\end{array}$ & Gender & N & Mean & $\begin{array}{c}\text { Std. } \\
\text { Deviation }\end{array}$ & t & sig \\
\hline \multirow{2}{*}{ Speaking } & Female & 53 & 2.88 & 1.13 & .339 & .735 \\
& Male & 19 & 2.78 & .85 & & \\
Listening & Female & 53 & 3.15 & 1.04 & -.424 & .673 \\
& Male & 19 & 3.26 & .80 & .96 & .407 \\
\multirow{2}{*}{ Test } & Female & 53 & 2.79 & .9633 & .623 \\
\hline
\end{tabular}

When the anxiety level difference between the scores of the first and fourth class students was examined, a statistically significant difference between groups was found. The anxiety level of the first graders was higher than the anxiety level of fourth graders. In other categories, a similar difference was observed $(\mathrm{p}<.01)$.

Table 3. Anxiety level differences between $1^{\text {st }}$ and $4^{\text {th }}$ graders

\begin{tabular}{lllcccc}
\hline $\begin{array}{c}\text { Anxiety } \\
\text { Category }\end{array}$ & Class & N & Mean & $\begin{array}{c}\text { Std. } \\
\text { Deviation }\end{array}$ & t & sig \\
\hline Speaking & $1^{\text {st }}$ year & 46 & 3.13 & 1.06 & 3.01 & .00 \\
Anxiety & $4^{\text {th }}$ year & 26 & 2.38 & .89 & & \\
Listening & $1^{\text {styear }}$ & 46 & 3.43 & .93 & 3.08 & .00 \\
& $4^{\text {thyear }}$ & 26 & 2.73 & .91 & & \\
Test & $1^{\text {styear }}$ & 46 & 3.10 & .84 & 3.40 & .00 \\
Anxiety & $4^{\text {th }}$ year & 26 & 2.38 & .89 & & \\
General & $1^{\text {st }}$ year & 46 & 2.95 & .78 & 3.65 & .00 \\
Anxiety & $4^{\text {th }}$ year & 26 & 2.26 & .72 & & \\
\hline
\end{tabular}

Similar to the class difference, when the mean score of the two age groups was compared, the findings validated that younger learners experienced more anxiety than the older ones (See Table 4).

Table 4. Anxiety level differences between two age-groups

\begin{tabular}{|c|c|c|c|c|c|c|}
\hline $\begin{array}{c}\text { Anxiety } \\
\text { Category }\end{array}$ & Age & $\mathbf{N}$ & Mean & $\begin{array}{c}\text { Std. } \\
\text { Deviation }\end{array}$ & $\mathbf{t}$ & sig \\
\hline $\begin{array}{l}\text { Speaking } \\
\text { Anxiety }\end{array}$ & $\begin{array}{l}18-21 \\
22-25\end{array}$ & $\begin{array}{l}46 \\
26\end{array}$ & $\begin{array}{l}3.13 \\
2.38\end{array}$ & $\begin{array}{l}1.06 \\
.89\end{array}$ & 3.01 & .00 \\
\hline Listening & $\begin{array}{l}18-21 \\
22-25\end{array}$ & $\begin{array}{l}46 \\
26\end{array}$ & $\begin{array}{l}3.43 \\
2.73\end{array}$ & $\begin{array}{l}.93 \\
.91\end{array}$ & 3.08 & .00 \\
\hline $\begin{array}{l}\text { Test } \\
\text { Anxiety }\end{array}$ & $\begin{array}{l}18-21 \\
22-25\end{array}$ & $\begin{array}{l}46 \\
26\end{array}$ & $\begin{array}{l}3.10 \\
2.38\end{array}$ & $\begin{array}{l}.84 \\
.89\end{array}$ & 3.40 & .00 \\
\hline $\begin{array}{l}\text { General } \\
\text { Anxiety }\end{array}$ & $\begin{array}{l}18-21 \\
22-25 \\
\end{array}$ & $\begin{array}{l}46 \\
26 \\
\end{array}$ & $\begin{array}{l}2.95 \\
2.26 \\
\end{array}$ & $\begin{array}{l}.78 \\
.72 \\
\end{array}$ & 3.65 & .00 \\
\hline
\end{tabular}

$(\mathrm{p}<.01)$

RQ3. What are the sources of speaking anxiety of the teacher trainees? 
All of the interviewed students (6) expressed high level of foreign language speaking anxiety. They expressed that they felt uncomfortable in the English speaking classes for several reasons. The sources of anxiety described by the students were grouped under three categories; instructor related, student related, and learning context related anxiety sources.

Table 5. The sources of speaking anxiety described by participants

\begin{tabular}{|c|c|c|}
\hline Theme & Categories & Codes \\
\hline \multirow[t]{3}{*}{$\begin{array}{l}\text { Sources of anxiety described } \\
\text { by the students }\end{array}$} & Instructor related (7) & $\begin{array}{l}\text { *Instructor is too strict (1), } \\
\text { *Instructor corrects the } \\
\text { mistakes (1) } \\
\text { *Being evaluated by the } \\
\text { instructors( } 4) \\
\text { *Instructors know a lot }(1)\end{array}$ \\
\hline & Student related (20) & $\begin{array}{l}\text { *Afraid of making mistakes } \\
\text { in front of the class( } 4 \text { ) } \\
\text { *Feel unrelaxed in front of } \\
\text { the peers ( } 3 \text { ) } \\
\text { *Lack of grammar and } \\
\text { vocabulary knowledge (3) } \\
\text { * Bored talking to both } \\
\text { friends and instructors (1) } \\
\text { *The obligation of taking } \\
\text { high scores (1) } \\
\text { *Receiving low score( } 2) \\
\text { Personality factor (being shy) } \\
\text { (1) } \\
\text { *Lack of self-confidence (5) }\end{array}$ \\
\hline & Learning context related (2) & $\begin{array}{l}\text { *Artificial language learning } \\
\text { context(1) } \\
\text { *Unwillingness to speak in a } \\
\text { formal environment (1) }\end{array}$ \\
\hline
\end{tabular}

It was seen that lack of self-confidence (5) fear of making mistakes (4), being evaluated by the instructors (4), feeling unrelaxed in front of the peers (3), lack of grammar and vocabulary knowledge (3), receiving low score (2), formal settings, formal/artificial language context, being corrected by the instructors were found to be some of the uncomfortable situations (See Table 5). Most of the participants (5 out of 6 ) expressed very low self -confidence during English speaking classes. All of the first year students expressed that they had speaking anxiety because they had low level of vocabulary and they did not have enough confidence. Some of the excerpts are given below.

S1. "I cannot be sure what I say, my voice starts tremble or I have low selfesteem at this time, of course".

S3. "If I could not explain myself, I would feel anxious. I think this is because of my lack of vocabulary knowledge. I don't care my grammar mistakes but I cannot explain myself when I do not remember a word".

S4. "I think I do not have enough knowledge of grammar or vocabulary. I have panic and cannot speak". 
Among the student-related anxiety reasons, the most striking finding was the level of the student confidence. They stated that due to their low level of vocabulary, they had low self-confidence. Skill-based courses throughout their training at university might increase their linguistic competence (grammar and vocabulary). That's why, it should be considered and extensive and intensive reading activities can also be supported.

All of the participants (6) expressed that they experienced high level of anxiety in classes and they felt more relaxed out of the class.

S1. "I am more nervous in the classroom rather than outside the classroom. Because I am afraid of making mistakes or using, the wrong structures while I am speaking English. I get nervous when I have to participate in speaking English in the classroom in order to take high grades".

S2. "I am more comfortable while I am speaking English outside the classroom. Because the language we speak in real life is more attractive and sincere. However, we speak an artificial and formal language in the classroom..."

S4. "I feel relaxed outside the classroom. I am afraid of making mistakes inside the classroom. I feel academic evaluation anxiety, while I am talking to my instructors. Nevertheless, the affective filter is low outside the classroom. So I can think and speak in English easily".

Table 6. The sources of anxiety described by trainers

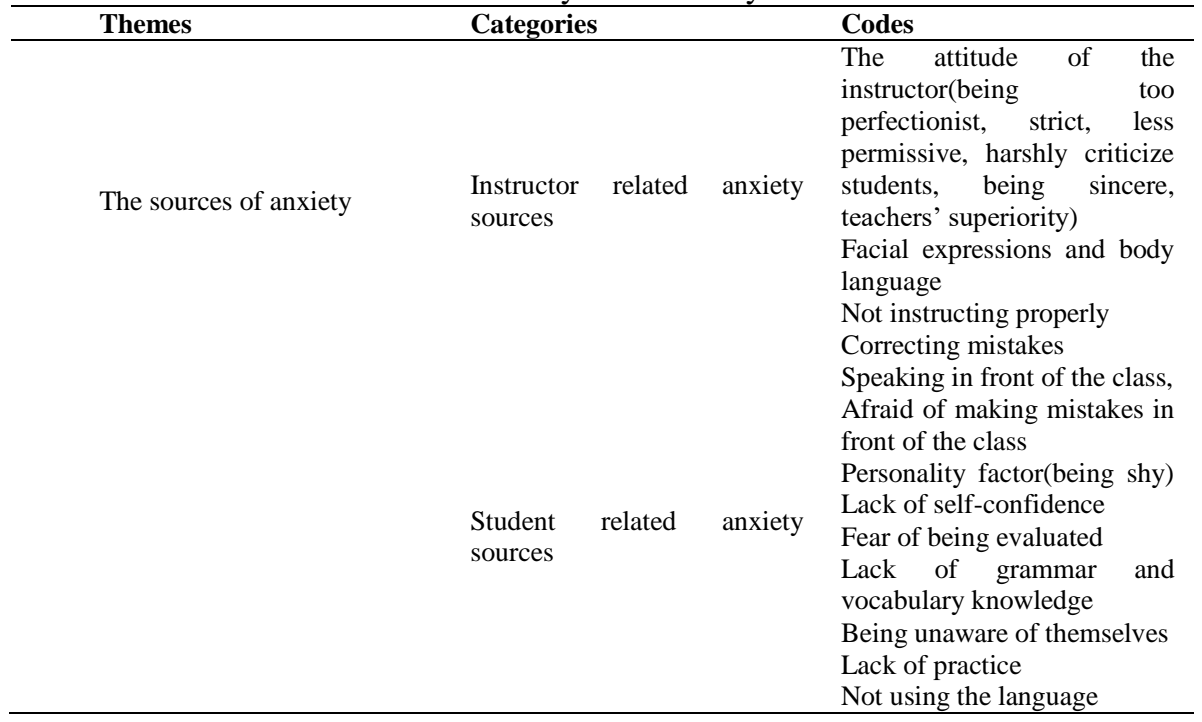

In the study, it was observed that the first graders felt more comfortable with their instructors however, the fourth graders were more comfortable with their friends. This is an interesting finding because the fourth graders have spent more time with their instructors and thus, it is expected that they have developed better relationship with them. It might be attributed to the skill-based courses that first-year-students have however, the fourth graders have more academic courses. They may need more practice on speaking to gain more confidence while communicating with the instructors. 
In the light of students' answers, while the first grade trainees were more comfortable with their instructors, the fourth graders were more comfortable with their friends. Half of the students (3) explained that they felt more comfortable while speaking English with their peers. They explained that their instructors' superiority and was a negative factor on them. They also did not feel themselves relaxed due to the role of the instructor as an evaluator. However, 2 of the trainees felt more comfortable while communicating with their instructors. Those students pointed out that they felt more relaxed because they found their instructors more knowledgeable and with their instructors' assistance they were able to produce language and that they received positive feedback from their instructors. Some of the excerpts are given below:

S4. "I am more relaxed while I am speaking to my peers. Because they have almost the same language proficiency like me and we, all know no one is perfect".

S5. "Of course, I feel comfortable with my friends. Instructors have academic knowledge in the class, this creates a tension, and I think they would evaluate me and my motivation gets lower".

S6. "I am easier with my friends. They do not judge me. I do not have any fear of making mistakes. Nevertheless, the instructors speak in English to us, even when we go to ask questions and this get me nervous".

S.3 "I am more relaxed with my instructors. Because they are knowledgeable person and the speech continues well. Whenever I talk to my friends, because of their lack of knowledge, the speech lasts short".

S.1 "I am more comfortable while speaking English with my instructors... While I am talking to my instructor in English, he or she corrects my mistakes and this is good for me to learn".

RQ4. What are the suggestions of the instructors to reduce the anxiety level of the students?

All of them suggested that they should help trainees increase their selfconfidence, develop close relationship with the students and employ humanistic approaches, create a relaxed atmosphere, express the aim of the activity clearly by giving instructions properly. They also pointed out the role of good classroom management. Some of the suggestions for trainees are; Trainees should participate in classroom activities (use language), read texts written in the target language, talk to themselves in the mirror, and be aware of their learning styles and learner characteristics, and become autonomous learners. 
Table 7. Suggestions of the trainers

\begin{tabular}{|c|c|c|}
\hline Themes & Categories & Coding \\
\hline Suggestions of the trainers & for trainers & $\begin{array}{l}\text { Develop close relationship } \\
\text { with the students } \\
\text { Employ humanistic } \\
\text { approaches, } \\
\text { Tell about their own anxiety, } \\
\text { Tell the facts about being } \\
\text { anxious } \\
\text { Smile and be more } \\
\text { sympathetic } \\
\text { Do not care about grades, } \\
\text { Good classroom } \\
\text { management, } \\
\text { Create a relaxed atmosphere, } \\
\text { Express the aim of the activity } \\
\text { clearly by giving instructions } \\
\text { properly }\end{array}$ \\
\hline & for students & $\begin{array}{l}\text { To become autonomous } \\
\text { learners } \\
\text { Employing strategies (Talk to } \\
\text { themselves in the mirror) } \\
\text { Ignore the mistakes, } \\
\text { Focus on recasting, } \\
\text { Participating in activities, } \\
\text { Believe in themselves/ } \\
\text { Increase self-confidence, } \\
\text { Use the target language } \\
\text { Be aware of themselves, } \\
\text { Listening to authentic } \\
\text { language, } \\
\text { Reading books/novels. }\end{array}$ \\
\hline
\end{tabular}

In the study, the quantitative data analysis results explored a moderate level of anxiety. However, after interviewing with students, it was observed that all of them had high level of anxiety. The difference between two types of data can be attributed to the limited number of participants in the interview group.

\section{DISCUSSION}

The research results showed that the trainees had a moderate level of speaking anxiety in the language classes. Listening and speaking anxiety received the highest mean. The qualitative data analysis also revealed that students had high level of anxiety in classes. In some studies, the anxiety levels of learners have been studied and the existence of considerable level of anxiety was explored (Ellis, 2008; Kunt, 2001; Şener and Çokçalışkan, 2016; Subaş1, 2010; Young, 1990). It was also seen that the listening and speaking anxiety levels of the students were close to test and general anxiety levels. This finding was confirmed by the interview students who expressed that they experience not only speaking and listening but also test anxiety. As the instructors suggested it is urgent that we should increase their self-confidence in order to decrease speaking anxiety, and give training to increase their self-confidence. Students' contact with learners of other nationalities may increase the development of their communicative competence and their motivation to learn a foreign language, and decrease their language anxiety. 
In the study, there was no significant difference between genders. This finding is in line with a number of studies (Aida, 1994; Alshahrani, 2016; Aydin, 2013; Çubukçu, 2008; Yassin, A. A. and Maasum, T. N. R. T. M., 2017; Şener, 2015; Şener and Çokçalışkan, 2016). However, it is a general view that anxiety thoughts influence girls more than boys, and they cannot control of worry and believe that it must be avoided (Bahrami and Yousefi, 2011). Some previous studies have suggested that females were more anxious males in language classes (Ezzi, 2012; Hismanoğlu , 2013; Kamarulzaman, M. H., Ibrahim, N., Yunus, M. M., and Ishak, N. M., 2013; Mesri, 2012). On the other hand, in a Taiwanese context, Hsu (2009) stated that males experienced higher level of anxiety than the females. Since there is not an agreement on this issue, in language classes, some thought control strategies maybe introduced to help both genders to control their feelings.

Krashen (1985) proposed that young learners have lower level of affective filter and thus their anxiety level should be lower as well. In the present study, however, younger trainees expressed more anxiety in language classes. Similarly, Aydin et al. (2006) revealed in their study that younger learners can feel less confident and be more anxious than older students. A parallel result was observed in Hismanoglu's, (2013) study at a university context. He stated that younger students had a stronger inclination to worrying about failing their foreign language classes, had a stronger inclination to getting nervous when the language teacher asked questions. In an elementary school context, Şener and Çokçalışkan 2016 also found that younger learners experienced more anxiety than did the older ones. However, there is not consensus on this issue. Er (2015) revealed that when children get older, they become more anxious. Since there is no consistency on this issue, the role of age needs to be searched in other contexts.

Participant trainees of this study expressed that they felt uncomfortable for various reasons. Among those; fear of making mistakes and negative evaluation of their peers and instructors, afraid of making mistakes in front of others and lack of self-confidence were the sources expressed by most of the participants. Other main sources were lack of grammar and vocabulary, and fear of receiving low score. Fear of making mistakes and negative evaluation of peers and instructors were in line with some other studies (Öztürk and Gürbüz's, 2014; Tunaboylu, 1993). Çelebi (2009) states that anxiety-provoking situations such as speaking in front of others and communicating with native speakers are important factors, which increase students' anxiety level. Besides, formal/artificial language use in the classroom is also important in terms of anxiety provoking situations and speaking anxiety or willingness according to the semi-structured interviews findings. The instructors should consider it. It is important that learner characteristics should be considered at all levels in the foreign language classes to help learners lower their affective filter.

Another anxiety source which was expressed by most trainees was low selfconfidence. Ellis (2008) sees it as a motivational factor affecting second language learning. It is accepted by most teachers that self-confidence is a critical variable and associated with high performance (Chastain, 1988). As Nunan (1999) reported sense of confidence is an important factor which influences learning, so the confidence level of the student should be increased by teachers by providing positive reinforcement, empathy and encouragement, and developing positive attitudes in foreign and second language classes. In order to be able to do this, they need to favor more contemporary teaching methods and employ more student-centered activities, reflect on their previous experience, and to have motivation to become more professional teachers. 
Considering the suggestions for anxiety provoking situations, instructors proposed that applying more humanistic approaches, being more competent regarding class management, developing positive attitudes, and giving classroom instructions were important factors to decrease anxiety of the learners. As İpek (2007) suggested, smooth manner of the teachers could help to eliminate the worry and negative emotional reaction aroused in classes.

\section{CONCLUSION}

This paper investigated the perceptions of teacher trainees and their trainers' regarding foreign language anxiety, and examined the impact of gender and age variables by collecting data from different sources by means of different tools. The analyses of the data revealed the existence of foreign language anxiety among trainees. When the role of age variable was investigated, younger trainees expressed more anxiety in language classes. According to participants' own perceptions, anxiety provoking situations were grouped under three categories, student related, trainer related, and situation related reasons. They described that the fear of being evaluated by their trainers, their negative attitudes during the lessons, immediate error correction and inadequate instructions were among the trainer related sources. Among student related reasons, lack of self-confidence, receiving low score, making mistakes, fear of negative evolution by peers and trainers, lack of grammar and vocabulary knowledge, were the most frequently reported reasons. They also did not feel relaxed at competitive classroom environment, and in class where formal language is required and used.

Research in educational settings points out that anxiety in language classes might influence learners' academic achievement in a negative way, and motivate the students to escape from the new learning tasks and communication activities. Hence, teachers should try to eliminate the worry and negative emotional reaction aroused in classes to increase the quality of language teaching and learning process. This study supports the view that the role of gender and age on anxiety are controversial matters and change from context to context. The findings of this particular study were based on a small Turkish population of ELT university students and gender characteristics may be different in other contexts.

In conclusion, anxiety is a unwanted negative affect that prevents learners from communicating freely, achieving more success, and using the target language in language classes. That is why; it is assumed that in foreign language classes learners need to be introduced some ways and strategies to handle with their anxiety. The researcher believes that teachers and trainees should be aware of learners' feelings and devote a lot of time and supplement courses with activities and task which can reduce anxiety, stress and negative feelings in the learning context. They should also increase students' contact with native speakers to have more natural teaching contexts. To finalize, we need professional language teachers, who love their profession, have enthusiasm to help learners learn a foreign language, favor lifelong learning, employ more contemporary approaches, and humanistic methods in their classes. 


\section{REFERENCES}

Aida, Y. (1994). Examination of Horwitz, Horwitz, And Copes construct of foreign language anxiety: the case of students of Japanese. Modern Language Journal, 78 (2), 155 - 168.

Alshahrani, M. A., (2016). The level of anxiety on the achievement of the Saudi EFL learners. Arab World English Journal (AWEJ), 7 (3), 65 - 76

Amiri, M. and Ghonsooly, B. (2015). The relationship between English learning anxiety and the students' achievement on examinations. Journal of Language Teaching and Research, 6, 4, 855-865.

Atas, M. (2015). The reduction of anxiety in EFL learners through drama techniques. Procedia- Social and Behavioral Sciences, 176, 961-969.

Aydın, S., Yavuz, F., and Yeşilyurt, S. (2006). Test anxiety in foreign language learning. Balıkesir University, Journal of Social Sciences Institute, 9 (16), $145-160$.

Bahrami, F., and Yousefi, N. (2011). Females are more anxious than males: A metacognitive perspective. Iranian Journal of Psychiatry and Behavioral Sciences 5(2), 83.

Batumlu, D.Z., and Erden, M.(2007). The relationshıp between foreign language anxiety and English achievement of Y1ldı Technical University School of Foreign Languages preparatory students. Journal of Theory and Practice in Education, 2007, 3 (1): 24-38.

Bergström, M. (2017). Foreign Language Speaking Anxiety in the Sweedish School Context: A comparative study of foreign language speaking anxiety and EFL course levels at Swedish upper secondary school. Retrieved September 28, 2017 from http://lnu.divaportal.org/smash/get/diva2:1137661/FULLTEXT01.pdf

Brown, D.H. (200). Teaching by principles: An interactive approach to language Pedagogy (2nd .Ed.). NY: Addison Wesley Longman Inc.

Büyükkarc1, K. (2016). Is it language learning anxiety and/or attitude of university students that determines their academic success? Turkish Online Journal of English Language Teaching (TOJET), 1, 2, 57-65.

Charmaz, K. (1983). The grounded theory method: An explication and interpretation. In R. M. Emerson (Ed. ), Contemporary field research (pp. 109-126). Boston Little, Brown.

Chastain, K. (1975). Affective and ability factors in second-language learning. Language Learning, 25:153-161.

Chastain, K. (1988). Developing second-language skills: Theory and practice $\left(3^{\text {rd }}\right.$ ed.). U.S.A: Harcourt Brace Jovanovich, Inc.

Çelebi, S. (2009). Teachers and Students' views on anxiety in English classrooms and attitudes towards English. Unpublished MA Thesis, Adana: Çukurova University.

Çubukçu, F. (2007). Foreign Language Anxiety. Iranian Journal of Language Studies, $1(2), 133-142$. 
Ellis, Rod. 2008. The study of second language acquisition. New York: Cambridge University Press.

Er, S. (2015). Foreign language learning anxiety of Turkish children at different ages. International Online Journal of Education and Teaching (IOJET), 2(2). 6878.

Ezzi, N. A. A. (2012). The impact of gender on the foreign language anxiety of the Yemeni university students. International Journal of Applied Linguistics \& English Literature, 1(2), 65-75.

Gardner, R.C., and Macintyre, P.D. (1991). An instrumental motivation in language study: Who says it isn't effective? : Studies in Second Language Acquisition, 13, 266-272.

Gass, S. M., and L. Selinker. (2008). Second language acquisition. USA: Routledge.

Glaser, B. G., and Strauss, A. L. (1983). The discovery of grounded theory: Strategies for qualitative research. Aldine Transcation.

Hismanoğlu, M. (2013). Foreign language anxiety of English language teacher candidates: A sample from Turkey. Procedia - Social and Behavioral Sciences, 93, 930- 937.

Horwitz, E. K. (1991). Preliminary evidence for the reliability and validity of a foreign language anxiety scale. In E. Horwitz, \& D. Young (Eds.), Language anxiety: From theory and research to classroom implications (pp. 141-150). Englewood Cliffs, NJ: Prentice Hall.

Horwitz, E.K., Horwitz, M. B., \& Cope, J. (1986). Foreign language classroom anxiety. The Modern Language Journal, 70, 2, 125-132.

Hsu, S. C. (2009). Foreign language anxiety among technical college students in English class. National Formosa University J. 28(1), 113-126.

İpek, H. (2007). Foreign language teaching anxiety. Eskişehir: T.C. Anadolu Üniversitesi.

Kamarulzaman, M. H., Ibrahim, N., Yunus, M. M., \& Ishak, N. M. (2013). Language anxiety among gifted learners in Malaysia. English Language Teaching, 6(3), 20.

Khairi, I. A., and Nurul Lina, A. R. (2010). A study on second language speaking anxiety among UTM students. Malaysia: University of Malaysia

Kim, Y. (1998). Communication and cross cultural adaptation. Clevedon: Multilingual Matters.

Krashen, S. (1985). The input hypothesis: Issues and implications. London: Longman.

Kunt, N. (2001). Do prospective teachers experience in foreign language anxiety?. In Osam U. V. and G. Celkan (Eds.), in searching for quality in ELT. 474-4879. Muenchen: Lincom, Europe.

Mesri, F. (2012). The Relationship between Gender and Iranian EFL Learners' Foreign LanguageClassroom Anxiety (FLCA). International Journal of Academic Research in Business and SocialSciences, 2(6), 147-156. 
Miles, M. B., and Huberman (1994). Qualitative data analysis. ( $2^{\text {nd }}$ ed.). Thousand Oaks, CA: Sage Publishings.

Nunan, D. (1999). Second language teaching and learning. USA: Heinle \& Heinle Publisher.

Öztürk, G., and Gürbüz, N. (2014). Speaking anxiety among Turkish EFL Learners: The case at a state university. Journal of Language and Linguistic Studies, 10(1) 1-17.

Pappamihiel, N. E. (2002). English as a second language students and English language anxiety: Issues in the main stream classroom. Research in the Teaching of English, 36(3), 327-256

Rastegar, M., and Karami, M. (2013). On the relationships among emotional intelligence, affective and social strategy use, and academic achievement of Iranian EFL learners. Theory and practice in language studies, 3, 2, 389-396.

Subaşı, G. (2010). What are the main sources of Turkish EFL students' anxiety in oral practice? Turkish Online Journal of Qualitative Inquiry, 1(2), 29- 49.

Şener, S.(2010)."Measuring anxiety level of Turkish university students". In D.Köksal; I. Erten; E. Z. Topkaya; A. Yavuz, (Eds.), Current trends in SLA research and language teaching. COMU Publications Number 99, 441-447.

Şener, S., (2015).Foreign language learning anxiety and achievement: a case study of the students studying at Çanakkale Onsekiz Mart University. Turkish Studies International Periodical for the Languages, Literature and History of Turkish or Turkic, 10 (3), 875-890.

Şener, S., and Çokçalışkan, A. (2016). The relationship between secondary school students' foreign language anxiety and success. Proceedings of international contemporary educational research congress. Ankara: Pegem Yayıncılık.

Tunaboylu, O. (1993). "Speaking through Association". Forum, 31(2), 47-48

Yılmaz, D., and Sakarya Maden, S. (2016). Dil öğrenim sürecinde Almanca öğretmen adaylarının kaygı tutumlarına ilişkin bir araştırma. Trakya Üniversitesi Ë̆itim Fakültesi Dergisi 6(2), 201-211.

Yükseltürk, E., and Bulut, S. (2009). Gender differences in self-regulated online learning environment. Educational Technology \& Society, 12 (3), 12-22

Young, D., J. (1990). An investigation of students' perspectives on anxiety and speaking. Foreign Language Annuals, 23,6,539-565. 


\section{Giriş}

\section{UZUN ÖZ}

Kayg1, dil öğrenim durumunu sorunlu ve stresli hale getiren, kontrol edilemeyen bir durum olarak tanımlanır. Horwitz ve arkadaşlarına (1986) göre kaygı nedenleri, gerginlik, kaygı, sinirlilik ve endişe gibi öznel duygular olabilir. Horwitz ve arkadaşları, yabancı dil kaygısının etkilerinin yabancı dil sınıflarında görüldüğünü ve kaygının, başarının güçlü bir göstergesi olduğunu ifade etmişler ve üç çeşit kaygı türü bildirmişlerdir. Yabancı dil kaygısına gelince, ikinci veya yabancı dili öğrenirken veya konuşurken yaşanan rahatsızlık duygusu, kaygı, sinirlilik ve endişe olarak tanımlanır. Benzer şekilde, Horwitz ve arkadaşları (1986, s.128), yabancı dil kaygısını, "dil öğrenme sürecinin benzersizliğinden kaynaklanan sınıfta dil öğrenmeyle ilgili öz algılamaların, inançların, duyguların ve davranışların bir oluşumu" olarak tanımlamışlardır.

Son yıllarda yabancı dil araştırmacıları kaygıların dil öğrenimi üzerindeki etkilerine büyük önem verdiler ve dil kaygısının yabancı dil edinimi ile en yakından ilişkili olduklarını gösterdiler (Horwitz ve diğerleri, 1986). Horwitz ve arkadaşlarının yabancı dil kaygısı ölçeğini kullanarak öğrencilerin kaygı düzeylerini belirlemek amacıyla çeşitli çalışmalar yapılmıştır. Bu çalışmalardan bazılarında öğrencilerin kaygı düzeyleri ve yabancı dil öğrenmede kaygı rolü üzerinde durulmuştur (Ellis, 2008; Gardner \& MacIntyre, 1993; Horwitz ve diğerleri, 1986; MacIntyre \& Gardner, 1989; Young, 1990). Bazı araştırmacılar, Türkçe bağlamında yabancı dil sınıflarında kaygı düzeyinin varlığını araştırdılar (Batumlu and Erden, 2007; Kunt, 2001; Şener, 2010; Şener ve Çokçalışkan, 2016; Subaşı, 2010 ve öğrencilerin yabancı dil sınıf kaygısı ve başarıları arasında negatif bir ilişki bulmuşlardır.

Kaygı ve başarı arasındaki ilişkiyi gösteren araştırmalar mevcut olsa da, bu çalışma, öğretmen adaylarının kaygı düzeyini ve hem onların hem de eğitmenlerin yabancı dil sınıflarındaki kaygı uyandıran durumlarla ilgili algılarını belirlemeyi amaçlamaktadır. Ayrıca, yaş ve cinsiyet bakımından genç ve yaşlı grupların kaygı düzeyleri arasındaki ilişkiyi araştırmayı amaçlamaktadır.

\section{Yöntem}

$\mathrm{Bu}$ makale öğretmen adaylarının yabancı dil konuşma kaygısı konusundaki algılarını araştırmayı amaçlamaktadır. Çalışmada tarama modeli kullanılmıştır. Çalışma, 2014-2015 öğretim yılı bahar döneminde Muğla S1tkı Koçman Üniversitesi İngiliz Dili Eğitimi Bölümü'nde gerçekleştirilmiştir. Araştırmanın örneklemi Muğla Sitkı Koçman Üniversitesi'nin İngilizce Dil Eğitimi Bölümünün 72 öğrencisi ve 3 öğretmen eğitmeninden oluşmaktadır. Nicel veriler, 26 birinci sınıf ve 46 dördüncü sınıf öğrencilerinden toplanmıştır. Nitel veriler ise bölümde çalışan 3 öğretmen eğitmeni ve 6 gönüllü öğrenciden toplanmıştır. Bu amaçla ilk olarak katılımcılara Horwitz, E. K., Horwitz, M.B. \& Cope, J. tarafından geliştirilen Yabancı Dil Sınıf Kaygısı Ölçeği (FLCAS) uygulanmıştır. Daha sonra nitel veriler, ölçeği tamamlayan altı öğrenciden yarı yapılandırılmış görüşmeler yoluyla toplanmıştır. En son olarak da, nitel veri toplamak için bölümden 3 ögretim üyesinden yarı yapılandırılmış görüşmeler yoluyla toplanmiştır.

\section{Bulgular ve Tartışma}

Nicel veri analizleri, öğrencilerin orta düzeyde yabancı dil endişesi yaşadığını gösterdi. Dinleme kaygısı ve konuşma kaygısı diğer kategoriler arasında en yüksek olarak bulundu. Birinci sınıf öğrencilerinin kaygı düzeyi, dördüncü sınıf öğrencilerinin kaygı düzeylerine göre daha yüksek bulundu $(\mathrm{p}<.01)$. Benzer şekilde, iki yaş grubu karşılaştırıldığında bulgular genç öğrencilerin yaşlılardan daha çok kaygı yaşadığını doğrulamıştır $(\mathrm{p}<.01)$. Aydın ve arkadaşları da (2006) yaptıkları çalışmada genç öğrencilerin daha yaşlı öğrencilere göre daha az güven duyduklarını ve kendilerini daha endişeli hissettiklerini ortaya koymuştur. Hismanoğlu'nun (2013) bir çalışmasında paralel bir sonuç gözlemlendi. Bununla birlikte, genc öğrencilerin daha fazla kaygı duydukları konusunda konuda fikir birliği yoktur. Er (2015) çalışmasında, Türk çocukları yaşlandıkça endişe seviyelerinin de yükseldiğini ortaya koymuştur. Bu konunun başka bağlamlarda araştırılması gerekiyor. Çalışmada, cinsiyetler arasında anlamlı fark 
bulunamamıştır. Bu bulgu, çeşitli çalışmalarda benzer şekildedir (Aida, 1994; Alshahrani, 2016; Aydın, 2013; Çubukçu, 2008; Yassin, A. A. ve Maasum, T.N.R.T.M, 2017; Şener, 2015; Şener ve Çokçalışkan, 2016 ). Bununla birlikte, kaygının kızları erkeklerden daha fazla etkilediği genel bir görüştür ve kaygıyı kontrol edemedikleri ve ondan kaçınılması gerektiğine inanilır (Bahrami ve Yousefi, 2011).

İçerik analizi yapılarak, nitel veriler analiz edilmiş görüşülen öğrencilerin tamamı (6) yüksek seviyede yabancı dil konuşan kaygı ifade etmişler ve çeşitli nedenlerle İngilizce konuşulan sınıflarda rahatsızlık duyduklarını ifade etmişlerdir. Hata yapma korkusu (4), eğitmenler tarafindan değerlendirilme (4) arkadaşlarının önünde konuşurken hoşnutsuzluk hissi (3), dilbilgisi eksikliği ve kelime bilgisi yetersizliği (3), kendine güven eksikliği (5) Düşük puan (2), formal ortamlar, öğretmenler tarafindan düzeltilmek gibi durumların bazı rahatsız edici durumlar olduğu tespit edilmiştir. Katılımcıların çoğu (6 kişiden 5'i) İngilizce konuşma derslerinde kendine güvenlerinin çok düşük düzeyde olduğunu dile getirmiştir. Ayni şekilde eğiticilerin tümü (3) öğrencilerin dil derslerinde başkalarıyla iletişim kurarken yüksek seviyede kaygı yaşadığını kabul ettiler. Hata yapma korkusu ve akranların ve eğitmenlerin olumsuz değerlendirilmesi gibi kaygı nedenleri diğer bazı araştırmalarla uyumlu bulunmuştur (Öztürk ve Gürbüz'in, 2014; Tunaboylu, 1993). Eğitmenler bu ifade edilen kaygı nedenlerini göz önüne almalıdırlar. Öğrencilerin öğrenme stillerinin ve özelliklerinin, yabancı dil sınıflarındaki her seviyede düşünülmesi ve öğrencilerin duygusal filtrenin düşürülmesine yardımcı olunması önemlidir.

Eğitmenlerin tamamı, öğrencilerin özgüvenlerini arttırmalarına, öğrencilerle yakın ilişki kurulmasına ve hümanist yaklaşımlar geliştirmelerine, rahat bir atmosfer yaratmalarına, doğru bir şekilde talimatlar vererek faaliyetin amacını ifade etmelerine yardımcı olmalarına gerek olduğunu ifade ettiler.

\section{Sonuç}

$\mathrm{Bu}$ makale yabancı dil kaygısı konusunda öğretmen adaylarının ve eğiticilerinin algılarını araştırmayı ve cinsiyet ve yaş değişkenlerinin rolünü incelemeyi amaçlamıştır. Nicel ve nitel verilerin analizleri, öğretmen adayları arasında yabancı dil kaygısının varlığını ortaya koymuştur. Yaş değişkeni rolü araştırıldığında, genç stajyerlerin dil sınıflarında daha fazla endişe duydukları ifade edilmiştir. Katılımcıların kendi algılamalarına göre kaygı uyandıran durumlar, öğrenci ilişkili, eğitici ilişkili ve duruma ilişkin nedenler olarak üç kategoride toplanmıştır.

Yapılan araştırmalar, dil sınıflarındaki kaygıların öğrencilerin akademik başarılarını olumsuz yönde etkileyebileceğini ve öğrencileri yeni öğrenme ile ilgili aktivitelerden ve iletişim etkinliklerinden kaçınmalarına neden olduğunu belirtmektedir. Dolayısıyla öğretmenler, endişeleri ve olumsuz duyguları ortadan kaldırmaya çalışmalıdır. Bu çalışma, cinsiyet ve yaşın kaygı üzerindeki rolünün tartışmalı konular olduğunu ve bağlamdan bağlama değiştiği görüşünü desteklemektedir. Bu çalışmanın bulguları ELT üniversite öğrencilerinin küçük bir Türk nüfusuna dayanmaktadır ve cinsiyet özellikleri diğer bağlamlarda farklı olabilir. 